\title{
"Mixing Pop (Culture) and Politics": Cultural Resistance, Culture Jamming, and Anti-Consumption Activism as Critical Public Pedagogy
}

\author{
JENNIFER A. SANDLIN \\ Arizona State University \\ Tempe, AZ, USA \\ JENNIFER L. MILAM \\ Texas AEM University \\ College Station, TX, USA
}

\begin{abstract}
Culture jamming, the act of resisting and re-creating commercial culture in order to transform society, is embraced by groups and individuals who seek to critique and (re)form how culture is created and enacted in our daily lives. In this article, we explore how two groups-Adbusters and Reverend Billy and the Church of Stop Shopping-use culture jamming as a means of resisting consumerism. We theorize how culture jamming as practiced operates as critical public pedagogy, through the ways in which it (1) fosters participatory, resistant cultural production; (2) engages learners corporeally; (3) creates a (poetic) community politic; and (4) opens transitional spaces through détournement (a "turning around"). We propose that when viewed as critical public pedagogy, culture jamming holds potential to connect learners with one another and to connect individual lives to social issues-both in and beyond the classroom. However, we also posit that culture jamming as critical public pedagogy is not a panacea nor without problems. We also discuss how culture jamming may in fact at times hinder critical learning by imposing a rigid presence on the viewer-learner that limits creativity and transgression, and how it risks becoming co-opted by the very market forces of capitalism it opposes.
\end{abstract}

"Todo lo compro de marca y consumo a todas horas. Mierda ahora estoy obligado a ser feliz!" [Everything I buy is brand name, and I shop all the time. Shit, now I'm forced to be happy!]

—Sign worn by a group of culture jammers called "Ecologistas en Acción" celebrating Buy Nothing Day (Día Sin Compras) in Madrid, Spain,

November 24, 2006, as they dressed up as disappointed consumers holding overflowing shopping bags and wailed and sobbed in busy streets and shopping malls in Madrid's busiest commercial centers

(c) 2008 by The Ontario Institute for Studies in Education of the University of Toronto.

Curriculum Inquiry 38:3 (2008)

Published by Wiley Periodicals, Inc., 350 Main Street, Malden, MA 02148, USA, and 9600 Garsington Road,

Oxford OX4 2DQ, UK

doi: 10.1111/j.1467-873X.2008.00411.x 
In the United States, many consumer economists call the day after Thanksgiving "Black Friday" and count it as one of the busiest shopping days of the year, as well as the official beginning of the holiday shopping season. During the most recent Black Friday (November 23, 2007), U.S. consumers spent $\$ 10.3$ billion (up $8.3 \%$ from 2006) in this postThanksgiving festival of consumption (ShopperTrak RCT Corporation, 2007). However, on this same day activists across the globe were celebrating a different cultural holiday, Buy Nothing Day (BND), which began in 1992 in Vancouver, Canada, and has spread to over 65 countries. BND brings together citizens who seek freedom from the manic consumer bingeing currently colonizing the holidays, and calls attention to the ecological and ethical consequences of overconsumption (Adbusters Media Foundation, 2007). Examples of recent activities from BND include the following:

- The "Space Hijackers," a group of activists in London, enacted the "Half Price Sale." Wearing T-shirts exclaiming "EVERYTHING IN STORE HALF PRICE TODAY!" they entered popular London retail stores and pretended to be employees, folding and straightening clothes and helping customers. They also placed leaflets explaining the philosophy of Buy Nothing Day in the pockets of the clothing items for sale.

- In Tokyo, activists collected free ad-carrying packs of facial tissue, which are typically given away in busy commercial shopping areas. Activists altered the ads and inserted Buy Nothing Day information sheets in the tissue packs before handing them out.

- In New York City, Reverend Billy and his Church of Stop Shopping held a Buy Nothing Day parade, which started at Macy's department store at 5 a.m. During stops along the parade route, Reverend Billy exorcized a cash register at Victoria's Secret and said an anticonsumption blessing in front of Old Navy.

We view these various "culture jamming" activities as examples of "anomalous pedagogies" (Ellsworth, 2005, p. 5) and critical public pedagogies. In this article we explore how community activist groups and others brought together by a shared vision of a more just society enact cultural resistance through the tactics of "culture jamming." In so doing, we also speculate on how the "public" - the audiences who view or engage with this activismmight experience these potential moments of critical learning.

Culture jamming is activity that counters "the continuous, recombinant barrage of capitalist laden messages fed through the mass media" (Handelman, 1999, p. 399). The term was coined in 1984 by the San Franciscobased eletronica band Negitivland in reference to the illegal interruption of the signals of ham radio (Carducci, 2006; Darts, 2004). Lasn (1999), founder of Adbusters Media Foundation, explains that culture jamming is a metaphor for stopping the flow of consumer-culture-saturated media. 
And Atkinson (2003) explains that culture jamming is based on the idea of resisting the dominant ideology of consumerism and re-creating commercial culture in order to transform society. Culture jamming includes such activities as billboard "liberation," the creation and dissemination of antiadvertising "subvertisements," and participation in DIY (do-it-yourself) political theater and "shopping interventions."

Many culture jammers view themselves as descendents of the "Situationists," a European anarchist group from the 1950s led by Guy Debord (Harold, 2004). Members of this group created moments of what Bakhtin (1973) and Kristeva (1986) would later call the "carnivalesque," enacted to fight against the "spectacle" of everyday life. The carnival, for Bakhtin (1973), is created using folk humor positioned outside the officially sanctioned culture of those in power. The spectacle is everything-advertising, television, and so forth-comprising society's "spectacular level of commodity consumption and hype" (Lasn, 1999, p. 100); it is a theatrical performance that obscures and legitimizes "violent production and consumption" (Boje, 2001, p. 437). According to the Situationists, the spectacle stifles free will and spontaneity, replacing them with media-sponsored lives and prepackaged experiences (Lasn, 1999). Like the Situationists, culture jammers reject the spectacle in favor of authenticity.

In this article we explore how two groups-Adbusters and Reverend Billy and the Church of Stop Shopping-use culture jamming as a means of resisting consumerism; we chose these groups because they are among the more widely known and enduring culture jamming groups. To frame our research, we draw from cultural studies and the critical curriculum literature focusing on public pedagogy. Specifically, we ground our work in a "Gramscian" cultural studies framework. This perspective conceptualizes popular culture as an active process, where cultural commodities and experiences are not simply passively consumed, but are the raw materials people use to create popular culture, within various contexts of power relations (Storey, 1999, 2006). From this view, popular culture is a prominent sphere in which inequalities of class, gender, race, and sexuality are made meaningful or brought to consciousness; it is also an arena for power struggles between dominant and subordinate social groups-a terrain on which hegemony, or consent, is fought for and resisted (Hartley, 2002; Storey, 2006).

This Gramscian view of cultural studies is apparent in the work of critical curriculum scholars, especially those who focus on popular culture as a site of public pedagogy. However, much of the public pedagogy literature emphasizes how popular culture perpetuates dominant values such as racism, sexism, homophobia, xenophobia, machismo, and violence (Mayo, 2002), rather than its counterhegemonic possibilities. This work includes studies of various sites of public pedagogy, including the practices of corporations such as Calvin Klein (Giroux, 1997), Nike (Tavin, Lovelace, Stabler, \& Maxam, 2003), Disney (Giroux, 1999; Tavin \& Anderson, 2003), 
and McDonald's (Kincheloe, 2002); and the ideologies of films such as GhostWorld (Giroux, 2003b), Dirty Dancing (Giroux \& Simon, 1989), and Fight Club (Giroux, 2001). Although we see the importance of exploring how people are raced, classed, and gendered through popular culture, we also believe it is imperative to investigate popular culture as a form of resistance (Denzin, 2003; Duncombe, 2002; Solórzano \& Delgado Bernal, 2001). Through our examination, we seek to "criticalize" the notion of "public pedagogy" and thus expand the concept of "critical public pedagogy" (Giroux, 2000, p. 355, emphasis ours).

While scholars in other disciplines have recognized culture jamming as a mode of communication (Harold, 2004) and as consumer resistance (Handelman, 1999), too little research within education-with some exceptions, including researchers within critical art education (Darts, 2006; Freedman, 2003; Kincheloe, 2003; Springgay, 2005; Stuhr, 2003; Tavin, 2003), and educators who enact and research performance pedagogy (Boal, 1985; Denzin, 2003; Garoian, 1999)—has focused on how popular culture can act as critical pedagogy. This is surprising given the many manifestations of critical public pedagogy occurring in popular and public culture, including the work of activists and artists such as The Guerilla Girls, Guillermo Gómez-Peña, James Luna, Adrian Piper, and The Yes Men. However, despite a handful of studies of public pedagogy as a means of resistance (e.g., Martin, 2005), much work in the area of "critical public pedagogy" has remained theoretical, consisting mainly of "calls to action" (Brady, 2006; Giroux, 2000, 2003a, 2003c, 2004a, 2004b, 2004c; Pozo, 2005) and has been harshly criticized for perpetuating "highly abstract and utopian" ideals that reinforce repressive myths and perpetuate hegemonic relations (Ellsworth, 1988, p. 298). Moreover, while art education scholars have examined how culture jamming may be used in schools to promote civic engagement with images, society, and identities (Tavin et al., 2003), much of this work is new, remains largely theorized, and is not widely implemented in general or art education contexts. Like Mayo (2002) and Giroux (2004b), we see the need to explore specific practices of critical public pedagogies, in order to understand how they operate.

We find Ellsworth's (2005) most recent work on public pedagogy helpful in our exploration; she urges critical educators to explore what she calls "anomalous places of learning"-museums, public art installations, films, and other forms of popular culture. We engage with her idea of the "pedagogical hinge" (p. 5) to examine culture jamming as critical public pedagogy, and to discover how culture jamming functions as a powerful site of learning. In addition, we borrow from Ellsworth a way of thinking about education within popular culture as a process rather than a product, and seek to understand how knowledge is created and experienced by the "learning self in the making" (p. 2). To Ellsworth, public pedagogy is most powerful when it creates "transitional spaces"-when it connects our inner selves to people, objects, and places outside of ourselves. 
Finally, we focus on culture jamming groups specifically addressing issues of consumerism and overconsumption, following Reynolds's (2004) recent call for curriculum scholars to explore work that resists "the brandname corporate order" (p. 32). Reverend Billy and Adbusters are part of a wider social movement focused on resisting consumerism and consumption that has received little attention among educational researchers; this movement includes groups working toward labor rights, fighting against the destructive consequences of globalization and advocating for fair trade, raising awareness about global sweatshops, and fighting against the ecological destruction that accompanies massive overconsumption. This social movement "attempt[s] to transform various elements of the social order surrounding consumption and marketing" (Kozinets \& Handelman, 2004, p. 691). While a handful of educators have focused on various social movements that resist consumption (Jubas, 2006; Sandlin, 2005; Sandlin \& Milam, 2007; Spring, 2003; Usher, Bryant, \& Johnston, 1997), we believe educators need to pay more attention to consumption, given the increasing role it plays in structuring every aspect of our lives and in fostering gross social and economic disparities (Bocock, 1993; McLaren, 2005).We thus place our work in the context of recent concerns of critical curriculum scholars about the increasing power of global corporate hypercapitalism and the imperialism of commercialism which shape the educational messages of popular culture while eradicating any public sphere not controlled by the market (Giroux, 2003c; McLaren, 2005).

\section{THE CASES OF ADBUSTERS AND REVEREND BILLY AND THE CHURCH OF STOP SHOPPING}

We draw from multiple sources of data for this project. Following Ellsworth (2005), we used secondary data from scholars in other disciplines who have researched and written about culture jamming, and from culture jamming activists who participate in, record, and write about their activism- "the words and concepts of others"-as "raw material" (p. 13). We also analyzed data from two culture jamming groups, Adbusters and Reverend Billy and the Church of Stop Shopping. To examine Adbusters, we gathered textual and visual material from its Web site, including blogs, articles, and "subvertisements"; 10 issues of Adbusters magazine published between 2003 and 2006; and a curriculum guide for high school teachers published by Adbusters that focuses on critical media literacy. To examine Reverend Billy and the Church of Stop Shopping, we gathered textual, visual, and audio material from its Web site, including blogs, MP3s of Reverend Billy's "sermons," photographs, and public performance "scripts" written by Reverend Billy. We also examined two recent documentaries (Post \& Palacios, 2006; Sharpe, 2001) containing interviews with Reverend Billy, footage of Reverend Billy enacting performance interventions, and footage of 
Reverend Billy preaching in various venues. Finally, we examined Reverend Billy's recent autobiography (Talen, 2003).

We sought in our analysis to make sense of how culture jamming operates as curriculum. Duncombe (2002) explains that when analyzing cultural resistance, one must examine four aspects: the content of the resistance, the form it takes, the ways it is interpreted, and the activities of its creation. We viewed the various forms of data we gathered-including visual, written, and performative-as "cultural texts," and drawing upon McKee's (2003) approach to interpretive cultural textual analysis, we sought to understand how culture jammers viewed and critiqued the world around them, how they created alternative visions of the world, and how they articulated these visions to others. To further understand culture jamming as curriculum, we also drew upon ethnographic or qualitative media analysis (Altheide, 1987, 1996), which focuses on the ethnography of cultural texts and consists of the "reflexive movement between concept development, sampling, data collection, data coding, data analysis, and interpretation" (Altheide, 1987, p. 65). Altheide (1987) further explains that this type of analysis is embedded in constant discovery and constant comparison, but seeks to go beyond description of the content of texts, to arrive at understanding of broader social discourses created by and reflected in the texts.

Adbusters is a magazine produced by the Adbusters Media Foundation. Based in Vancouver, Canada, Adbusters describes itself as "a global network of artists, activists, writers, pranksters, students, educators and entrepreneurs who want to advance the new social activist movement of the information age. Our aim is to topple existing power structures and forge a major shift in the way we will live in the 21st century" (Adbusters Media Foundation, n.d.). The content of Adbusters focuses on two main themeshow marketing and mass media colonize space, and how global capitalism and rampant consumption are destroying natural environments (Rumbo, 2002). Adbusters magazine (Figure 1) is a reader-supported, not-for-profit magazine with an international circulation of 85,000 and contains readergenerated materials, commentaries by activists from across the globe, and photographs and stories depicting readers' social activism. Adbusters also hosts a Web site (http://www.Adbusters.org/) where activists can read about anti-consumption campaigns; download posters, stickers, and flyers for distribution; and share information about their own activism. Some of Adbusters' ongoing campaigns include Buy Nothing Day (described earlier) and TV Turnoff Week (a week in April where individuals are encouraged to take a break from the incessant commercial messages coming through their televisions by just turning them off; instead of watching TV, Adbusters encourages people to interact with others and become involved in community activism).

Reverend Billy is an anti-consumption performance artist based in New York City, and the leader of the Church of Stop Shopping. Bill Talen, whose 


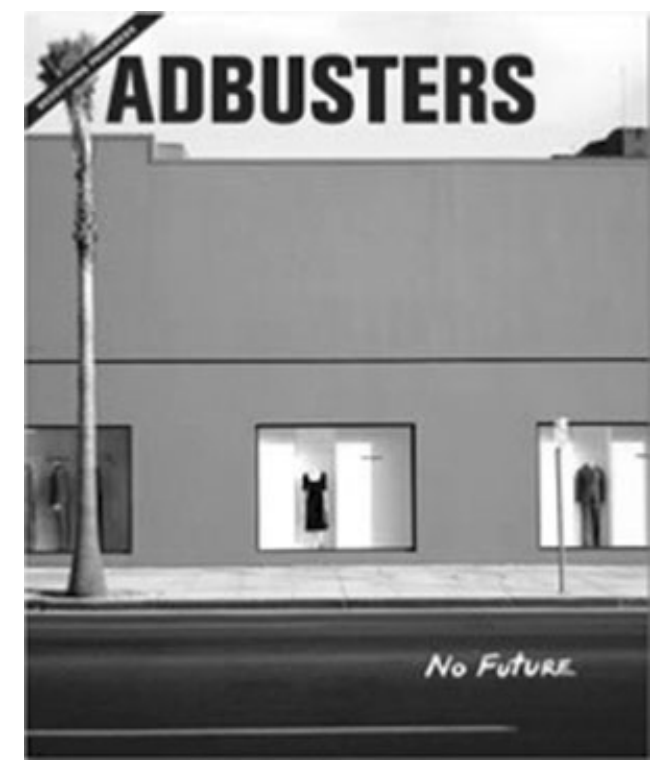

FIGURE 1.

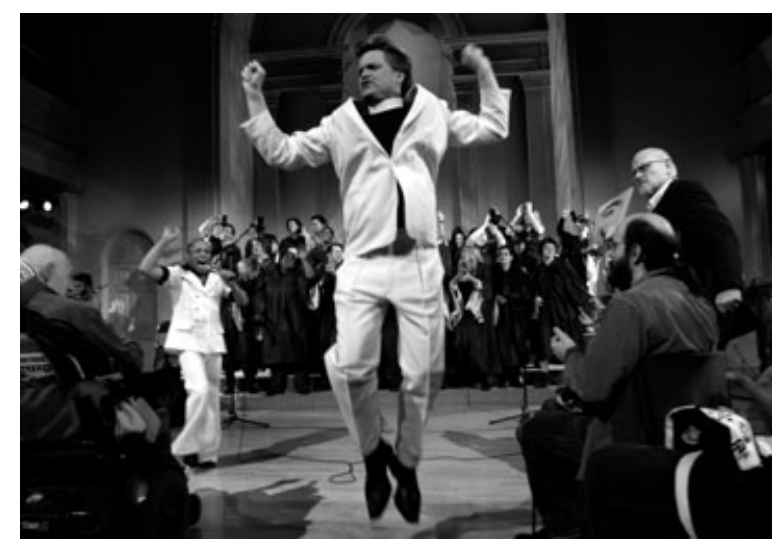

FIGURE 2.

stage character is Reverend Billy, adopts the persona of a Southern, conservative, evangelical preacher-à la Jimmy Swaggart—including pouffy hair and a white suit (Figure 2).

He stages "comic theatrical service[s]" (Lane, 2002, p. 60)—structured as comic church services- with "readings from the saints (or the devils), public confessions, collective exorcisms, the honoring of new saints, donations to the cause, a lively choir, and a rousing sermon" (Lane, 2002, p. 61). 
During these services, he acts out a call-and-response style of preaching as the audience responds with Amens! and Hallelujahs! Reverend Billy also performs "retail interventions" in public spaces and retail stores along with the Stop Shopping Gospel Choir; some of his popular targets of anticonsumption activism include the Disney Company, Starbucks, Wal-Mart, and Victoria's Secret. In addition, Reverend Billy writes "intervention manuals" and scripts that other activists can use in their own public theater jams.

\section{GULTURE JAMMING AS GRITICAL PUBLIC PEDAGOGY}

Our analysis focused on how and why culture jamming activists enact what we position as critical public pedagogy. Given the nature of our datawhich focuses primarily on the activities of the jammers themselves, and much less on audience members' reactions-we portray the espoused and enacted pedagogy of culture jamming, and at this point can only speculate about how audiences receive that pedagogy; we hope in future research to focus more on audience reactions. We posit that culture jamming operates as potentially powerful pedagogy through the ways in which it seeks to foster participatory cultural production, engages with the learner and the "teacher" corporeally, and aims to foster the creation of a community politic. We further argue that culture jamming's "pedagogical hinge" lies in the ways it aims to produce a sense of "détournement" in audience members, which can operate as a form of "transitional space." Finally, while we recognize culture jamming's potential pedagogy of possibility (Giroux \& Simon, 1988), our analysis also revealed moments of coercion and compliance-what we call culture jamming's "loose pedagogical hinge"which can shut down rather than encourage the possibility of counterhegemonic transgression (hooks, 1994).

\section{Fostering Participatory, Resistant Cultural Production}

Ellsworth (2005) argues that the question of pedagogy is "how to use what has already been thought as a provocation and a call to invention" (p. 165, emphasis ours). Powerful pedagogies thus engage learners as creators. Critical pedagogy advocates argue that learners should become cultural producers and build new, more democratic cultural realities (Giroux, 2004c). One aspect of culture jamming's potential power as critical pedagogy, then, lies in how it seeks to foster participatory cultural production. In our current condition of hypercapitalism (Graham, 2006) grounded in consumption, it is a defiant notion that individuals are capable of and should be responsible for their own entertainment (Duncombe, 1997); yet 
it is this very ideal that culture jammers promote. Duncombe (1997) also posits that current cultural critique necessarily involves a critique of consumerism, arguing that "any vision of a new world must include a new vision of how culture and products will be produced and consumed" (p. 105). This new vision involves culture jammers becoming cultural producers and creators who actively resist, critique, appropriate, reuse, recreate, and alter cultural products and entertainment.

As evidenced by the varied Buy Nothing Day actions and the other explications of culture jamming described at the beginning of this article, culture jamming is enacted in many forms, all of which rely on creative cultural production and ultimately seek to challenge and change dominant discourses and practices of multinational corporations (Harold, 2004). Duncombe (2002) explains that cultural resisters shift from being consumers to being creators; indeed, this is what drove the genesis of Adbusters. Lasn (2006) explains:

We had this nasty feeling that "we the people" were slowly but surely losing our power to sing the songs and tell the stories and generate our culture from the bottom up. More and more, the stories were being fed to us top-down by TV networks, ad agencies and corporations ... [We wanted to take] the storytelling, culture-generating power back from commercial and corporate forces. (p. 85)

As a form of cultural resistance, then, culture jamming is a "free space" where artists and activists can "experiment with new ways of seeing and being" and where they can "develop tools and resources for resistance" (Duncombe, 2002, p. 5). Adbusters magazine, for instance, encourages reader submissions; readers create and contribute a majority of text and artwork in the magazine. These submissions range from "fake ads" (subvertisements); to critical musings on politics, the environment, fashion, culture, and nutrition; to visual artwork and poetry; to more journalistic or academic articles on a variety of topics (recent issues have featured articles on true cost economics, the Israeli-Palestinian crisis, and the effects of Agent Orange used in the Vietnam War). During his "revivals," Reverend Billy also invites audience members to participate: to sing along, confess their sins, or dance. Through his Web site, audience members can discuss issues and share strategies for creating more awareness among consumers; they can also find performance scripts that they can borrow, change, and enact in local contexts. We posit that culture jammers thus hope to turn typically passive activities into active ones in which they create culture rather than simply consume it. In doing so, they aim to redefine themselves and their relationships with consumption, and to redefine possibilities for the future.

Both Adbusters and Reverend Billy engage in cultural production as they alter and give new, resistant meanings to popular cultural symbols. Culture jammers interrupt how public spaces are typically used and understood "in ways that hold the potential for education to be contemporane- 
ous with social change and identities in the making" (Ellsworth, 2005, p. 58). Culture jammers thus clearly demonstrate how popular culture is a field of contestation. Adbusters, through its "subvertisements," plays with and gives new meaning to the "memes" of popular culture, including the iconography associated with multinational corporations such as McDonald's, Nike, Absolut Vodka, Tommy Hilfiger, Calvin Klein, and numerous others. Memes are media viruses that spread throughout society-for example, advertising jingles, quotes from movies and situation comedies, advertising slogans, and the like that "work their way into everyday conversations" (Duncombe, 2002, p. 369). Adbusters uses the forms of media that viewers are already familiar with, and takes advantage of the power of already-existing memes that are part of consumer consciousness. However, through subvertisements, Adbusters "jams" or disrupts dominant memes in ways that expose negative social, environmental, cultural, or ethical consequences of the practices of multinational corporations; in so doing, Adbusters lures viewers into interactions "with 'alternative' subject matter which poses as a 'dominant' media deployment" (Tietchen, 2001, p. 117). Thus Adbusters 'subvertisements operate like vaccines or antidotes to memes, as they shake us out of consumer trances and refocus our attention on messages that run counter to dominant media ideology (Boyd, 2002). If, as Lasn (1999) argues, "whoever has the memes has the power" (p. 123), then one potential avenue for social change lies in hijacking memes to disrupt and counteract the very messages they are trying to convey.

For example, Figure 3 appropriates the memes originally created and circulated by Calvin Klein's Obsession perfume advertising campaign. However, this subvertisement shows not a runway model which a reader might, at first glance, believe she/he is seeing, but instead an emaciated woman leaning over a toilet presumably to vomit. The subvertisement gives new meaning to the media-produced ideal of "thinness" and to the Calvin Klein brand by clearly associating it with eating disorders, and through pointing out the ethical and health consequences of too many young woman being influenced by the powerful fashion industry and its unrealistic standards of beauty.

Reverend Billy, too, plays with memes created and distributed by corporations such as Disney, Starbucks, and Victoria's Secret. For instance, during his "shopping interventions" at Disney retail stores, Reverend Billy and members of his church often carry large wooden crosses with Mickey and Minnie Mouse stuffed animals "crucified" on them. Reverend Billy explains:

The Disney Company is the high church of retail. And that's why we put Mickey Mouse on the cross. We're taking two great organized religions [Christianity and what he calls the Church of Consumerism] and grinding them together and trying to confuse people so they can think in a new way.... I want the symbols and meanings to fly away. (Reverend Billy, as interviewed in Post \& Palacios, 2006) 


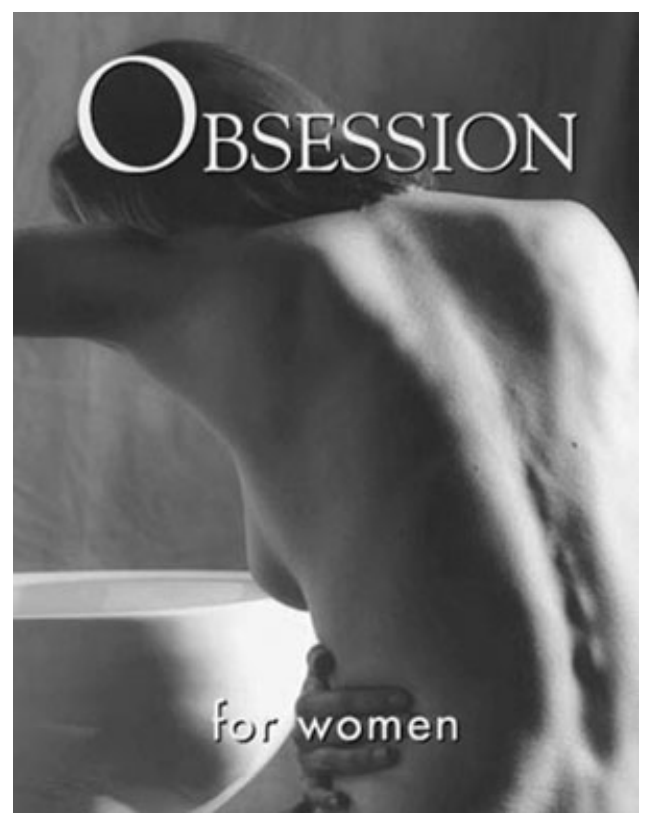

FIGURE 3.

Reverend Billy thus causes these memes to take on new meanings as they are incorporated into new, unexpected counterhegemonic cultural scripts. Mickey Mouse morphs from the Disney-sanctioned symbol of everlasting childhood and nostalgia to the leader of the evil, child-labor-sweat-soaked empire of Disney.

\section{Engaging Corporeally}

Ellsworth (2005) argues that effective pedagogy engages the whole learner. That is, powerful pedagogy "involves us in experiences of the corporeality of the body's time and space. Bodies have affective somatic responses as they inhabit a pedagogy's time and space" (p. 4). We argue that part of the potential power of culture jamming's pedagogy, then, lies in how it attempts to engage the whole person-including the body and emotions-in a process of "becoming." First, the act of culture jamming often literally involves the body. For instance, one of Reverend Billy's retail interventions literally engages jammers' and audience members' physical bodies. This intervention, targeted at Starbucks, is entitled "It's a Party! Bump and Grind the Buckheads" (Reverend Billy and the Church of Stop Shopping, n.d.), and involves jammers filling a Starbucks store and proceeding to 
dance, strip, and handout pamphlets describing the questionable ethics of Starbucks' business practices. Directions for this jam read:

Gather a large number of party-prone faithful. ... Print (on two sides) many copies of the Coverco report (which you can get at Coverco.org). Print it out in both English and Spanish. There are lousy things in that report about people who bring non-Fair Trade Coffee to market. The study took place in Guatemala, and a lot Starbucks' victims are kids. Instruct everyone to stuff the pages of this report into their trouser legs, stockings, panties, undershirts and bras. Now with this large throng of the party-prone, fill up a Starbucks until the ratio of people to floorspace is like SOB's on Saturday Nite. Go with saxophonists, kazoos and squeeze in a Trinidadian drum. And a blaster with Thelonius Monk on it. Press the ON button. Ask the musicians to play. Begin to dance. Everyone bumps and grinds while the shoppers try to sip their $\$ 4$ non Fair Trade lattes. The bumping and grinding gives way to increasingly articulate stripping. The reports fly out of the underclothing like bilingual white ravens. The sipping stops. Bump and grind them beans! (Reverend Billy and the Church of Stop Shopping, n.d., para. 15)

Reverend Billy explains the physical sensations culture jamming ignites when he describes how he delivers his message to his audience. He says he tries to lead "by example" in order to persuade people that it can be fun not to consume. He further explains that participants have to

Embody the fun. It all comes down to the decision, what sort of dance am I involved in here? Where are my arms, where are my hands? How far is my voice reaching, what am I saying? It's all physical. It's the physical-spiritual. It's sacralizing the ordinary. Once you take responsibility for that and you're willing to enter a state of heightened oddness in public space-or even public space that they claim is private [laughing]—you're by your example having fun outside their consumer strictures. (Quoted in Ashlock, 2005, para. 31)

Culture jammers also attempt to engage emotions when enacting culture jamming. Elsewhere (Callahan \& Sandlin, 2006; Sandlin \& Callahan, 2004) we have argued that culture jammers engage emotion to initiate action and interest amongst members of society. We believe emotion plays important roles in the responses or reactions culture jammers try to elicit in the spectators who experience their jams. For instance, we posit that Adbusters engages viewers emotionally, by transforming recognizable consumer appeals into images that shock and disturb viewers (Sandlin \& Callahan, 2004). Drawing upon our earlier work, we illustrate how Adbusters attempts to do this through the subvertisement below (Figure 4). Upon first glance, the viewer thinks she/he sees an advertisement for Nike shoes. This subvertisement draws on the recognizable meme distributed as the Nike "Why do I run?" campaign from the 1990s, which brought together photos of runners with inspirational explanations of why they run. A viewer familiar with the Nike memes should then think this subvertisement features a dedicated runner and that the text contains inspirational phrases about running. In a kind of double take, however, the viewer sees what the 


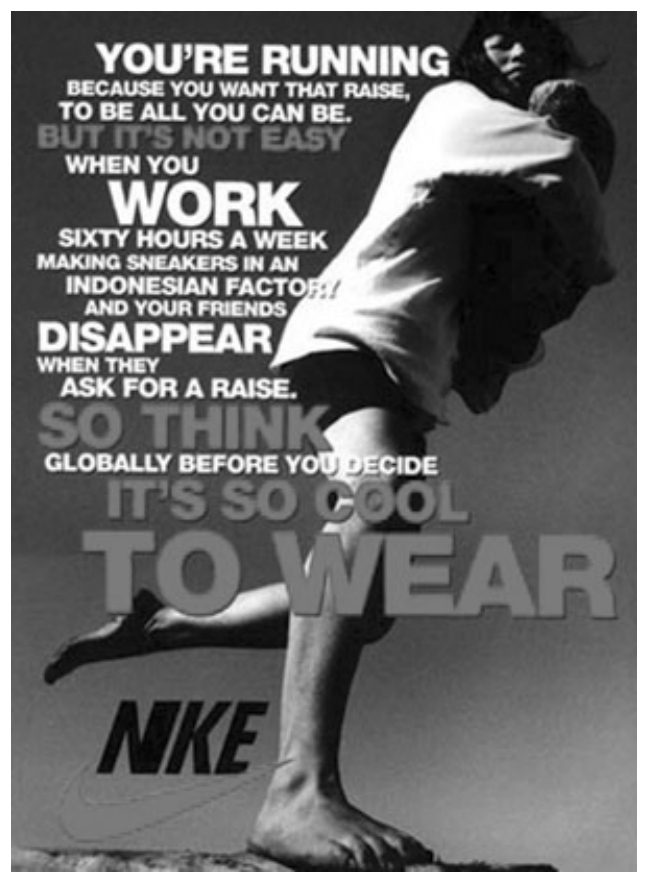

FIGURE 4.

ad really features-a worker in an Indonesian shoe factory who is running (barefoot, without the Nikes she makes but cannot buy) to escape the harsh working conditions she must endure to earn a fraction of the price the shoes actually sell for, to consumers much like the one viewing the ad. In this moment, the viewer feels off-balance because the expectations for and the reality of the ad are at such odds. This realization produces a variety of emotions in the viewer-outrage at the unfair labor practices and guilt over buying (perhaps, even at that moment wearing) Nike products-and hopefully shocks the reader into viewing the Nike company in a different light, and to changing his or her consumption practices with regard to Nike.

Reverend Billy, too, engages emotions in his work. He says that when he is preaching:

It feels GREAT! . . I feel SO GOOD preaching in a Disney store! . . It is time to be rude. It is time to be embarrassed. If you really do something that just makes you SHAKE with the feeling of being inappropriate, you've probably found a strut, a structure of their culture that was supposed to be there. (Reverend Billy, as interviewed in Sharpe, 2001)

This emotional energy is also felt among some audience members who witness Reverend Billy's performances, as evidenced by data we gathered 
that focuses on audience reactions. For example, one audience member wrote to Reverend Billy (at http://www.revbilly.com) to explain his emotional reaction to viewing one of Reverend Billy's public appearances:

HELLO REV.! i heard you on the Majority Report wed. night as i sat in my car ( $\square 90$ volvo, a real mess) and watched the beautiful snow flakes whirl about. it could not have been more powerful. your words about buying gifts within walking distance really moved me ... yes, i AM a consumer sinner. i feebly try to do the best i can, and feel guilty about not doing enough! commercial society repulses me and the last thing $\mathrm{i}$ want to do is feed the beast that tries to rule our planet. i am weak. but your message helps me stay strong and inspires me to keep working and spread the word of CHANGE!!!! . . . Bill

In this passage we see evidence of an emotional reaction consisting of the reader suddenly feeling moved; we posit that this reaction helped stir up a sense of hope within the reader that is leading to a reconceptualization of his identity.

Engaging corporeally does not mean simply engaging the physical body and internal emotions, however. Within culture jamming, we also see evidence of the kind of engagement of what Springgay and Freedman (2007) call the imaginary body. That is, Springgay and Freedman draw upon and extend the recent focus on the body in curriculum studies to engage not just the physical body, but also the social products of the body and the ways that bodies are shaped in culturally specific ways as they act and are acted upon. In viewing the body as having and constructing meaning in and of itself and in relation to other bodies, Springgay and Freedman are particularly concerned with "inter-embodiment." As Weiss (1999) explains, embodiment is never a solitary experience; rather, it is constantly mediated as we interact with others. We posit that it is precisely this "inter-embodiment" that lends culture jamming its power as a way to engage participants with othersvisually, spatially, through imagination and literally-where one "touches and is touched by others" (Springgay \& Freedman, 2007, p. xx).

We argue that through engaging corporeally, culture jamming thus helps to establish a strong relationality-or consciousness of being "with" others. Springgay and Freedman (2007) suggest that a "bodied curriculum" questions, examines and provokes particularities of different bodies rather than accepting a homogenized and normalized conception of the body. Thus, we posit that culture jamming-through its use of the physical as well as visual representations of the body in various forms-is an example of a critically bodied curriculum. Culture jamming as critical public pedagogy pushes participants to (re)consider their understandings of themselves, their relationships with others, and the interaction of their subjectivities within society for the purposes of questioning and challenging the current political and social milieu. This is accomplished through "rewriting" hegemonic discourses of societal symbols and challenging viewer-learners to "move beyond modes of passive spectatorship and towards more active and 
expressive forms of communication with and in the world around them" (Darts, 2004, p. 325).

\section{Creating a [Poetic] Community Politics}

An important part of Ellsworth's (2005) "democratic civic pedagogy" is how it puts us in new relationships "with our selves and with our others" (p. 96). Ellsworth believes powerful pedagogy must "create places in which to think about "we" (p. 95, emphasis ours). We argue, then, that a powerful aspect of culture jamming's pedagogy is the ways in which it seeks to create community. Drawing upon St. Clair's (1998) discussion, we view community as relationship. That is, communities are formed and maintained as individuals form relationships with each other; as St. Clair (1998) argues, community is not the result of interaction, it is interaction itself. Community relationships are also sites of cultural production and reproduction. In addition, community relationships help to develop and support shared value systems and social activism (St. Clair, 1998). As we saw above, engaging corporeally is but one way culture jamming seeks to create a sense of community. In addition, the act of collaborative cultural production-creating culture together-also discussed earlier, and the act of sharing that culture with others helps culture jammers and their audiences move toward creating community. In this way, the public in critical public pedagogy, includes culture jammers themselves, those witnessing the jams directly, and those who may interact with media, texts, and artifacts indirectly thereafter. Indeed, Duncombe (2002) argues that through this sharing and creating process, culture thus "becomes a focal point around which to build a community" (p. 6). For instance, Church of Stop Shopping member Jason Grote (2002) recalls the sense of community occurring among culture jammers during recent interventions in the Disney store:

I have noticed that there is a collective upswell of emotion that seems to occur at demonstrations, or at least at the good ones. I think it would be dangerous if I were to feel it more often: a mix of inspiration, sentimentality, camaraderie, selfrighteousness, righteous anger, abject fear, and what I think Che Guevara must have been talking about when he said that the true revolutionary was guided by great feelings of love: a deep, abiding compassion for everything and everyone. (p. 359)

Kalb (2001), in an article on Reverend Billy, also posits that culture jamming creates a sense of community among the audiences or viewers of jamming activities:

Flooding the halls he [Reverend Billy] performs in with an astonishing torrent of righteous words about the spell of consumer narcosis, he ends up offering hundreds of hard-core artsy skeptics (often in their twenties) their first chance ever to 
shout "Hallelujah!" and engage in Pentecostal call-and-response. In so doing, they find themselves possessed of a precious community that is not accessed via flickering screens, as well as a delightful channel for various inchoate angers that he has done them the service of naming. (p. 164)

Thus, culture jammers like Reverend Billy offer audiences members ways of relating to each other that they may have never experienced before.

The community culture jammers seek to create is not just any kind of community, however-it is a community drawn together with a sense of political purpose and a community that engages in what Brookfield (2005, p. 31) calls "political learning." The creation of community is, in fact, necessary for the enactment of culture jamming's politics. Brookfield (2005), following Gramsci, argues that critical consciousness, or political learning, cannot form in an individual without that individual becoming part of a collective public. Critical consciousness thus forms in groupscommunities_as people learn about their common situations and the need for collective political action. Culture jamming, however, hopes to create political community through a very different kind of political engagement than traditional party politics or traditional social movement activism. Adbusters founder Kalle Lasn (1999) argues that traditional social movement strategies cannot bring about the kinds of change culture jammers seek. With regard to the traditional political "Left," Lasn (1999) states that they lack passion; he argues that "there's something drab and predictable about them; they feel like losers" (p. 118), and states that individuals who want to build an effective social movement must use new tactics. This new paradigm of political activism involves the creative appropriation, creation, and enactment of culture, along with large doses of humor and creativitythis approach works by creating a political poetics. In an interview, Reverend Billy explains:

I'm using strategies like entertainment, comedy, music, and then of course working with small groups of people inside transnational chain stores inside the private property of the enemy, of the great retail juggernaut-that also is much more fun-it's charged and less predictable than a demonstration that has its didactic language and a set of terms that are very old. (As interviewed in Post \& Palacios, 2006)

We believe that part of culture jamming's potential effectiveness as critical public pedagogy, then, is its ability to help participants to engage in communal politics. When politics becomes poetic, and is presented or enacted through culture-and especially through a fun, exciting, collective experience of culture-it can seem more open and inviting, and less predictable, than other forms of political protest (Duncombe, 2002). 


\section{Culture Jamming's Pedagogical Hinge: Opening Transitional Spaces Through Détournement}

Pedagogical "hinges" refer to those aspects of spaces of learning that make them pedagogically powerful. More specifically, the "hinge" refers to some aspect of pedagogy that puts "inside and outside, self and other, personal and social into relation" (Ellsworth, 2005, p. 38). Pedagogy's hinges create possibilities for both inside and outside-self and society-to be disrupted and refigured. We believe an important pedagogical moment-culture jamming's pedagogical hinge-occurs when audience members as learners experience détournement (literally, a "turning around"). All of the pedagogical tactics used in culture jamming attempt to lead the learner to a moment of détournement, where she is no longer who she used to be, but rather is caught off guard by the possibility of becoming someone or something different. Lasn (1999) argues that culture jamming helps provide a new way of looking at the world, and describes this détournement as "a perspective-jarring turnabout in your everyday life" (p. xvii).

Through moments of détournement, culture jammers seek to move audience members away from scripted "spectacle-driven" experiences through igniting authenticity. As one culture jammer writing in Adbusters stated, "Is your life a project? Do you give a shit about anything? Can you still get angry? Be spontaneous?" (Unattributed artist, 2003). Lasn (1999) also describes how détournement can provide people with new, more authentic choices about how to live and how to be:

You are-everyone is-a creator of situations, a performance artist, and the performance, of course, is your life, lived in your own way. . . Many times a day, each of us comes to a little fork in the path. We can then do one of two things: act the way we normally, reflexively act, or do something a little risky and wild, but genuine. (p. 100)

And Lane (2002) describes how Reverend Billy invites consumers to step away from the well-defined script of consumption:

While many audiences mistake the performance for simple boycott gestures, Talen's [Reverend Billy's] point is not to end the day's shopping. Rather, the goal is to arrest it long enough to make the underlying psycho-social investments of the scene visible. While he speaks tongue-firmly-in-cheek of "saving the souls" of his unsuspecting consumer-audiences through these interventions, he is, indeed, hoping to release their imaginations from the strictures of consumer practice. (pp. 68-69, emphasis ours)

Détournement also involves stepping away from one's self, and suspending that self in the "unknown." In an interview conducted by Sharpe (2001) after a "shopping intervention" inside a Disney store, Reverend Billy explains this moment of détournement: 
I love it if I see someone and their jaw's down and their eyes are ... [demonstrates a confused look] ..."What is this?-What is this guy doing-What? Mickey's the devil but he's not a Christian?-What?-What?-Is he an actor or is this a stunt?"And you can see them looking at the cameras they're trying to add it up-as soon as they can add it up it's less important to them. If that suspension takes place for two or three or four minutes, they're gonna take that home and they're gonna still be thinking about it a week later. They might even hesitate to buy a Disney product. (Sharpe, 2001)

According to Ellsworth (2005), this suspension constitutes a powerful learning moment, as learning happens when the self is dissolving. Reverend Billy seeks out this dissolution and sees it as the moment of the possibility of change. He explains:

I consider the Disney store and Starbucks and so on-places were I might be arrested-as theaters, stages. They're stages. They're charged.... When I'm preaching there, people kinda go-_pauses, looks around with a confused expression on his face]... . Their consciousness floats out away from their faces. They are no longer in possession of themselves and that's good-that means something real might be changing in them or something. (Post \& Palacios, 2006)

Further, we believe that this moment of détournement has the potential to operate as a form of transitional space. "Transitional spaces" (Ellsworth, 2005) are spaces of play, creativity, and cultural production; they help us bridge the boundaries between the self and the other. When in those spaces, "we are entertaining strangeness and playing in difference. We are crossing that important internal boundary that is the line between the person we have been but no longer are and the person we will become" (Ellsworth, 2005, p. 62). Our data highlighting audience reactions indicate that when experiencing culture jamming, audience members sometimes experience détournement and move into transitional spaces. Jason Grote, now a member of the Church of Stop Shopping, experienced a moment of détournement the first time he encountered Reverend Billy. We quote him at length to emphasize the significance of his response.

He seemed to stir an honestly ecstatic religious impulse in that small theater. The moment I remember most about that show is a bit wherein he holds a conversation with a giant billboard of the model Kate Moss. "She's looking at me," he fumes. "She wants me." He continues to flirt with the billboard and in so doing is transported back to an early adolescence romance. Suddenly, he realizes: this is my self. These are my memories. These ads are taking our memories, attaching them to products, and selling them back to us. He stops, horrified. We are completely with him. This world is fallen and so are we. He leads us in a healing ritual, a visualization wherein we see a Disney tchotchke, reach for it, then resist the temptation to buy. We are given the following directive: "Remember your name." It occurred to me that day how branded I am. There is a huge chunk of my memory that is someone else's property, property that someone is right now making money off of. I think about the tattoo of Bugs Bunny on my right shoulder blade. It is trademarked, licensed to the tattoo company by AOL Time Warner. (Grote, 2002, p. 363) 
Reverend Billy describes these moments of détournement as moments where "a bright, unclaimed space opens up" (Talen, 2003, p. xii). He goes on to state that:

Consumers think it is a vacuum. It is really only the unknown-full of suppressed ocean life, glitterati from Bosch, DNA twists, and childhood quotes that if remembered would burn down the Disney store. (Talen, 2003, p. xii)

Based on Grote's (2002) response, quoted above, and other audience reactions, one of which is cited later in this paragraph, we contend that these moments of détournement may help audience-members-as-learners to envision and begin to enact what Giddens (1991) calls "life politics"wherein people begin seeing their individual lives as intertwined with others' lives and with social issues, and begin enacting "civil labor," which involves individuals engaging politically with the commons in order to increase the social capital of everyone (Rojek, 2001). The work of both Reverend Billy and Adbusters is aimed at engaging détournement through helping expose the connections between individual actions and global social, economic, and environmental issues. For instance, by incorporating information about the harsh working conditions in Nike sweatshop factories into what otherwise looks like it should be an inspirational or uplifting Nike advertisement, the Adbusters Nike subvertisement presented above turns the original ad's message on its head and exposes the labor politics behind the Nike corporation; this is done in order to assist readers to rethink just how "cool" it is to wear Nikes and to support that multinational corporation. And in a sermon cited in Lane (2002) from March 26, 2000, in support of the unionization of local bodega workers, Reverend Billy describes a moment where he began connecting his individual life choices to others' lives. Lane (2002) states that this sermon

Includes an anecdote about buying coffee at a local deli. As he [Reverend Billy] reaches for the can on the shelf, his arm freezes in mid-gesture, before touching the product. "I'm having a moment of accidental entry into another world," he says, as he narrates a lyrical but lurid vision of the coffee plantation where the beans were grown, replete with underpaid growers and threatening goon squads and rich children of the overseers flying to resort towns...he is "seeing backward, upstream, into who made this, who worked, who lived, who gave, who was stopped ..." [he says:] "I realized, I was not alone. Next to me is a man. He's been standing there for a long time, but now I see him." The presence of the worker, underpaid and exploited in circumstances comparable to those that produced the sweatshop coffee, has prompted all exploited and fetishized labor to be momentarily revealed. (p. 76)

Lane (2002) goes on to explain that after Reverend Billy tells the worker's story, he then urges the audience to follow him out of the building and into the streets to participate in an action at the bodega. One audience member, witnessing one of Reverend Billy's shopping interventions inside 
a Disney store, reveals how a moment of détournement moved her to begin connecting self and society in a new relationship:

I'm offended that Disney has sweatshops. I can see Kathy Gifford, but Disney? Disney? I'm gonna check it out, I'll tell you, ?cause I spend a lot of money in Disney. Disney with all their billions of dollars, that's the least they can do is pay a decent wage and not to underage children. (Audience member, as interviewed in Sharpe, 2001)

We believe these various examples show how détournement operates as a form of transitional space. That is, as détournement can help make clear and trouble our habitual responses to experiences (Ellsworth, 2005). Transitional spaces suspend time and space and thus allow us room to think of other ways of enacting particular moments. Transitional spaces introduce "a stutter, a hesitation" and interrupt "the binary logics that keep self/ other, inner/outer, individual/social locked in face-to-face opposition," thus allowing us to relate to ourselves and others in new ways (Ellsworth, 2005 , p. 64). The learning moment within transitional spaces is similar to the Deleuzian "in-between" (Reynolds, 2004), Jarvis's (2006) notion of "disjunction," and what Pinar (2004) calls "currere," where the self is always positioned in relation to others.

We argue that it is in these spaces that the viewer-learner begins to (re)consider her/his role in society, both as an individual and in relation to others. We contend that culture jamming as critical public pedagogy fosters human agency and democratic participation in the public sphere by opening said "transitional spaces" where détournement is a possibility for those involved. We further argue that these moments of détournement are desirable for all learners-a moment or space for the learner to (re)consider her/his ideas or conceptions of the text, artifact, or situation. Whether learners actually experience a turning around is ultimately left to their desires and will-however, it is this opportunity that critical public pedagogy potentially provides and we believe is most desirable.

\section{Culture Jamming's Loose Pedagogical Hinge?}

Ellsworth (2005) argues that the "space" in transitional spaces refers to the kinds of educational environments that facilitate new, creative, spontaneous ways of learning and of seeing the self in relation to others. While culture jamming often facilitates the opening of such spaces, our data analysis led us to believe that it also sometimes creates environments that hinder rather than support learning-as-transgression (hooks, 1994). Some audience members, upon experiencing a culture jam, react with anger not at consumerism but at the culture jammers themselves. For instance, in one culture jamming action captured on film by Sharpe (2001), Reverend Billy 
preaches against sweatshops and corporate power in a Walt Disney store. Immediately following the performance, Sharpe's videographer captures two women in the audience engaging in a conversation. One of the women says to the other:

I'm just offended by what just happened in the store. Where I spend my money and where I go to shop is my business and not anyone else's. Especially an idiot like whoever he was. (Audience member, as interviewed in Sharpe, 2001)

At another performance, Reverend Billy and members of his "congregation" are performing outside in front of the Times Square Disney store, and as part of their action they are holding large wooden crosses with Mickey Mouse and Minnie Mouse "crucified" on them. An angry man walks up and yells, "Take the mouse off the cross! Because I'm a Catholic and I find that very, very offensive-that you're taking a symbol of my religion and putting a friggin' toy on it like it means nothing. It is very, very offensive" (as interviewed in Sharpe, 2001).

Audience members also react negatively against Adbusters. A participant in an online discussion about culture jamming stated, for instance:

I HATE Adbusters. Why? Because they have this preachy holier-than-thou attitude. In the same way that MADD public service announcements make me want a double Maker's Mark on the rocks, and "Smoking Is Really, Really Bad For The Children" ads make me want a big fucking cigar, Adbusters make me want to do nothing more than rent a Ford Excursion and drive straight to McDonald's. And I doubt I'm the only one who feels that way. (Sulli, 2002)

Another participant on a different forum simply proclaims, "I hate adbusters for being propagandistic" (Miriam, 2004). In these examples, it is evident that rather than (re)considering their own subject position or participation in what culture jammers would deem the social and political hegemony of popular culture, the viewer-learner views the jammers (and their actions) as offensive, judgmental, and oppressive. This "holierthan-thou" attitude comes across in Adbusters magazine, as contributors and editors define for readers how they are supposed to think and live, and sometimes rant against what they perceive as "consumer sheep." For instance, in the July/August 2003 issue, contributor Hunter S. Thompson asks, "Who does vote for these dishonest skinheads? Who among us can be happy and proud of having all this innocent blood on our hands? Who are these swine? These flag-sucking half-wits who get fleeced and fooled by stupid little rich kids like George Bush? .. I I piss down the throats of these Nazis" (cited in Activistcash.com, 2007, para. 29).

This oppressive aspect of culture jamming echoes Ellsworth's (1988) critique of critical pedagogy, as she explains that the very attempt to put into practice the elements of critical public pedagogy espoused in the literature leads to the reproduction of domination as the discourse works in 
repressive ways not intended. In line with Ellsworth (1988), these audience members are reacting to a form of oppression-the assumption that anticonsumption ideology is somehow a preferred moral condition and that anyone not in agreement is immoral or wrong. We believe that these examples demonstrate that despite culture jamming's potential for fostering critical pedagogy, it can also at times become a space where critical learning is squelched. Ellsworth (2005) explains a similar distinction when she describes the differences between learning-in-the-making-asexperience and learning-as-compliance. Culture jammers must try to avoid become "saboteur[s] of personal development" (Ellsworth, 2005, p. 75), much like the "unattributed voice" squelching the ideal of open-ended and unforced play in the Art Inside Out exhibit discussed at length by Ellsworth (2005). While this exhibit opened creative pedagogical spaces and invited children to play there, they also contained aspects that inhibited free creative play. Alongside quotes from the featured artists highlighting their thoughts about their creative processes, there were also blocks of "unattributed text" (p. 74) that provided interpretations of the artwork and guidelines to "assist children's comprehension of the myriad concepts at play in contemporary art" (Ellsworth, 2005, p. 75). Ellsworth calls this unattributed voice a "rigid, imposing, preemptive presence" (p. 75) that limited creativity rather than enhanced it.

Culture jammers must, then, strive to revel more in possible, playful spaces, where the "learning self of the experience of the learning self is invented in and through its engagement with pedagogy's force" (Ellsworth, 2005, p. 7). These transitional spaces operate as engaging learning sites because the learning self is invited to play, to explore, to investigate partial knowledges in the making, and is not dictated by the "final correct answer" (Ellsworth, 2005, p. 76). In the final section of this article, below, we explore how culture jammers can work to keep learning spaces open and transitional, and discuss some of the challenges they face in doing so.

\section{TOWARD OPENING TRANSITIONAL SPACES}

In a recent article focusing on the brand-name corporate order currently permeating American schools, Reynolds (2004, p. 29) asks, "Where are the confrontations, the protest, and the resistance?" While Reynolds concludes that there has yet to be a "major political or policy battle on classroom commercialization" (p. 29), we respond to his question by pointing to the important activist work focused on commercialism in schools—see, for instance, the film Captive Audience (Media Education Foundation, 2003). We also, however, believe that when the terrain of pedagogy is widened to include spaces outside formal educational institutions, many more sites of resistance appear. Understanding the workings of public pedagogy is critical if we are to begin to explore how we are shaped by, and shape our own, 
culture. We also want to note, however, that while our research focuses on two culture jamming groups operating outside the formal classroom, there is still much to be garnered from such an exploration by those working within traditional school buildings. As Darts (2004) writes, "Although it may not, for instance, be desirable to instruct students in the art of jamming billboards, educators can still meaningfully engage their classes in forms of creative and critical production inspired by culture jamming" (p. 324). Furthermore, learners are shaped by and help shape popular culture-and they bring those learning selves-steeped in popular culture-into the classroom. As we posit elsewhere (Sandlin, Milam, O'Malley, \& Burdick, 2007), we believe that if educators ignore the pedagogical force of popular culture, we risk operating under the false assumption that schools are closed systems-a position strongly questioned by theorists such as Giroux (2000) and Ellsworth (2005).

We view culture jamming as a form of resistance that is potentially aligned with resistance theories within critical curriculum studies. Within the notion of resistance lies a celebration of the power of human agency, and a recognition that individuals are not merely passive dupes or victims of powerful social structures (Solórzano \& Delgado Bernal, 2001). Rather, resistance theories focus on the power of human agency to question, reject, modify, or incorporate dominant ideologies and cultures. Denzin (2003) explains how resistance can be enacted through public, cultural performances wherein the performer-as-cultural-critic takes sides to "show how a participatory, feminist, communitarian ethic addresses situations of injustice" (p. 199). However, while we see the potential of culture jamming to foster critical learning, as a form of cultural resistance and critical public pedagogy it is not a panacea; it is not without contradictions and potential problems. As we explored, when culture jamming insists on the "right answer," culture jamming can also work against critical learning and close down rather than open transitional spaces. Similar to Ellsworth's (1988) experience in developing a critical curriculum in her classroom, culture jamming may in fact reinforce repressive myths by attempting to dictate who people should be and what they should think, rather than allowing for the open "talking back"- the "defiant speech that is constructed within communities of resistance" (p. 310). We must be mindful of the tendency of critical public pedagogy to rely too heavily on "rationalistic tools" that "fail to loosen deep-seated, self-interested investments" based on typically European, White, male, middle-class, Christian, able-bodied think and heterosexual ideals.

Therefore, critical educators interested in the counterhegemonic possibilities of public pedagogy must learn how to foster spaces of transition, and to learn to avoid closing those spaces by imposing predetermined moral positions already constructed. We believe an important part of this learning involves avoiding certainty and encouraging exploration-what Ellsworth (1988) calls a "pedagogy of the unknowable." In this pedagogy, 
narratives and ideas are always partial- "partial in the sense that the meaning of an individual's or group's experience is never [completely] self-evident or complete" (p. 318). Indeed, we posit that the work of culture jammers is most powerful when it demonstrates the pedagogical force of not dictating "the final correct answer" (Ellsworth, 2005, p. 76). Reverend Billy, for instance, attempts-and often, but not always, succeeds-to leave spaces open to be digested, (re)created, and acted upon by audience members themselves. We posit that an important part of leaving these spaces open involves Reverend Billy's ability to implicate himself in his critique and thus more easily form relationships with his audiences than Adbusters, which more often points critique outward. Kalb (2001), for instance, argues that "what sets him apart from other theatrical prophets of capitalist excess, however, is his understanding that effective critique must point inward and outward at the same time" (p. 165). As evidence of this understanding, Kalb (2001) cites his Web site which encourages readers to confess their shopping sins. Furthermore, Reverend Billy consistently acknowledges his own "state of sin" with regard to consumerism. At one performance captured on film by Post and Palacios (2006), in response to a woman named Carol who has confessed to him her sin of being afflicted with "American Affluenza," he responds, "Sister! First of all I just want to say, Sister Carol—[sings softly]—We are all sinners."

Another issue that could potentially interrupt culture jamming's potential as critical public pedagogy is closely connected to the seemingly infinite capacity of capitalism to commodify dissent. Culture jamming has been critiqued because of how it "hijacks" dominant culture, and essentially makes the medium of mainstream commercial culture voice counterhegemonic messages. In effect, because culture jammers "turn the power of commercial culture against itself” (Duncombe, 2002, p. 328), they must wrestle with these questions: "When you/hijack a vehicle do you carry along a bit of its meaning? That is: when commercial media is pirated for radical messages do these messages become mere entertainment or product? And conversely: When the image of hip rebellion sells a product, does it also sell the image that rebellion is hip?" (Duncombe, 2002, pp. 327-328). Reynolds (2004) also highlights the ability of capitalism to commodify dissent, and discusses the ease with which capitalism removes the possibility of resistance from artistic creations, through turning them into commodities and effectively co-opting them.

Giroux and others call for learners to learn how to create their own culture-to become cultural producers building new, more democratic cultural realities and spheres. We contend that critical researchers need to continue to move past simply critiquing and deconstructing current hegemonic and oppressive cultural narratives, and look to social movements as activism-as-curriculum that are seeking to actively produce new, resistant pedagogy using popular culture. As Giroux (2003c) eloquently explains, academics need to connect with and learn from activists and others 
involved in social change. As a site of critical public pedagogy, culture jamming highlights ordinary people working collectively for social change. We encourage other critical researchers and educators to continue to explore the potential of culture jamming and to locate other sites of resistance within civic spaces. We feel that these inquiries could provide educators new ways of understanding educational practice, both within and outside of schools.

\section{REFERENCES}

Activistcash.com. (2007). Adbusters. Retrieved April 28, 2007, from http:// www.activistcash.com/organization_overview.cfm/oid/36

Adbusters Media Foundation. (n.d.). About Adbusters. Retrieved January 5, 2007, from http://www.adbusters.org/network/about_us.php

Adbusters Media Foundation. (2007). Buy Nothing Day press release 2007. Retrieved November 27, 2007, from http://adbusters.org/metas/eco/bnd/ view.php?id=403

Altheide, D. L. (1987). Ethnographic content analysis. Qualitative Sociology, 10(1), 65-77.

Altheide, D. L. (1996). Qualitative media analysis. Thousand Oaks, CA: Sage.

Ashlock, J. (2005). Shopocalypse now!: $Q+A$ with Reverend Billy [Electronic Version]. RES Magazine, 8. Retrieved January 5, 2007, from http://www.res.com/ magazine/articles/shopocalypsenowqawithreverendbilly_2005-05-19.html

Atkinson, J. (2003). Thumbing their noses at "the man": An analysis of resistance narratives about multinational corporations. Popular Communication, 1(3), 163180.

Bakhtin, M. M. (1973). Rabelais and his world (H. Iswolsky, Trans.). Cambridge, MA: MIT Press.

Boal, A. (1985). Theatre of the oppressed. New York: Theatre Communications Group.

Bocock, R. (1993). Consumption. London: Routledge.

Boje, D. M. (2001). Carnivalesque resistance to global spectacle: A critical postmodern theory of public administration. Administrative Theory and Praxis, 23(3), 431-458.

Boyd, A. (2002). Truth is a virus: Meme warfare and the billionaires for Bush (or Gore). In S. Duncombe (Ed.), Cultural resistance reader (pp. 369-378). New York: Verso.

Brady, J. F. (2006). Public pedagogy and educational leadership: Politically engaged scholarly communities and possibilities for critical engagement. Journal of Curriculum and Pedagogy, 3(1), 57-60.

Brookfield, S. D. (2005). The power of critical theory: Liberating adult learning and teaching. San Francisco: Jossey-Bass.

Callahan, J. L., \& Sandlin, J. A. (2006). Culture jamming and emotional hegemony: Exploring consumer resistance within a postemotional society. In F. A. Nafhuko (Ed.), CD-ROM Proceedings of the Academy of Human Resource Development Conference, Reference page, 20-2, Columbus, $\mathrm{OH}$.

Carducci, V. (2006). Culture jamming: A sociological perspective. Journal of Consumer Culture, 6(1), 116-138.

Darts, D. (2004). Visual culture jam: Art, pedagogy, and creative resistance. Studies in Art Education, 45(4), 313-327.

Darts, D. (2006). Art education for a change: Contemporary issues and the visual arts. Art Education, 59(5), 6-12. 
Denzin, N. K. (2003). The call to performance. Symbolic Interaction, 26(1), 187-207.

Duncombe, S. (1997). Notes from underground: Zines and the politics of alternative culture. London: Verso.

Duncombe, S. (2002). Cultural resistance reader. New York: Verso.

Ellsworth, E. (1988). Why doesn't this feel empowering: Working through the repressive myths of critical pedagogy. Harvard Education Review, 59(3), 297324.

Ellsworth, E. (2005). Places of learning: Media, architecture, and pedagogy. New York: Routledge.

Freedman, K. (2003). Teaching visual culture: Curriculum aesthetics and the social life of art. New York: Teachers College Press.

Garoian, C. (1999). Performing pedagogy: Toward an art of politics. Albany: State University of New York Press.

Giddens, A. (1991). Modernity and self-identity: Action, structure and contradiction in social analysis. Berkeley: University of California Press.

Giroux, H. A. (1997). Channel surfing: Race talk and the destruction of today's youth. New York: St. Martin's.

Giroux, H. A. (1999). The mouse that roared: Disney and the end of innocence. Lanham, MD: Rowman \& Littlefield.

Giroux, H. A. (2000). Public pedagogy as cultural politics: Stuart Hall and the "crisis" of culture. Cultural Studies, 14(2), 341-360.

Giroux, H. A. (2001). Public spaces/private lives: Beyond the culture of cynicism. Lanham, MD: Rowman \& Littlefield.

Giroux, H. A. (2003a). Utopian thinking under the sign of neoliberalism: Towards a critical pedagogy of educated hope. Democracy E Nature, 9(1), 91-105.

Giroux, H. A. (2003b). Neoliberalism and the disappearance of the social in Ghost World. Third Text, 17(2), 151-161.

Giroux, H. A. (2003c). Public pedagogy and the politics of resistance: Notes on a critical theory of educational struggle. Educational Philosophy and Theory, 35(1), 5-16.

Giroux, H. A. (2004a). Cultural studies, public pedagogy, and the responsibility of intellectuals. Communication and Critical/Cultural Studies, 1(1), 59-79.

Giroux, H. A. (2004b). Public pedagogy and the politics of neo-liberalism: Making the political more pedagogical. Policy Futures in Education, 2(3\&4), 494-503.

Giroux, H. A. (2004c). Cultural studies and the politics of public pedagogy: Making the political more pedagogical. Parallax, 10(2), 73-89.

Giroux, H. A., \& Simon, R. I. (1988). Schooling, popular culture, and a pedagogy of possibility. Journal of Education, 170(1), 9-26.

Giroux, H. A., \& Simon, R. I. (1989). Popular culture as a pedagogy of pleasure and meaning. In H. A. Giroux \& R. I. Simon (Eds.), Popular culture, schooling, and everyday life (pp. 1-29). New York: Bergin \& Garvey.

Graham, P. W. (2006). Hypercapitalism: New media, language, and social perceptions of value. New York: Peter Lang.

Grote, J. (2002). The God that people who do not believe in God believe in: Taking a bust with Reverend Billy. In S. Duncombe (Ed.), Cultural resistance reader (pp. 358-369). London: Verso.

Handelman, J. M. (1999). Culture jamming: Expanding the application of the critical research project. Advances in Consumer Research, 26, 399-404.

Harold, C. (2004). Pranking rhetoric: "Culture jamming" as media activism. Critical Studies in Media Communication, 21(3), 189-211.

Hartley, J. (2002). Communication, cultural and media studies: The key concepts. London: Routledge.

hooks, b. (1994). Teaching to transgress. New York: Routledge. 
Jarvis, P. (2006). Towards a comprehensive theory of human learning. London: Routledge.

Jubas, K. (2006). The trouble with shopping: Discourses, practices and pedagogies of the consumer-citizen. Proceedings of the 47th Annual Adult Education Research Conference, 196-202.

Kalb, J. (2001). The gospel according to Billy. Theater, 31(3), 161-167.

Kincheloe, J. L. (2002). The sign of the burger: McDonald's and the culture of power. Philadelphia: Temple University Press.

Kincheloe, J. L. (2003). Artful teaching in a "sensational" context. In K. Rose \& J. Kincheloe (Eds.), Art, culture E education: Artful teaching in a fractured landscape (pp. 1-37). New York: Peter Lang.

Kozinets, R. V., \& Handelman, J. M. (2004). Adversaries of consumption: Consumer movements, activism, and ideology. Journal of Consumer Research, 31, 691704.

Kristeva, J. (1986). Word, dialogue, and novel. In T. Moi (Ed.), The Kristeva reader (pp. 35-61). New York: Columbia University Press.

Lane, J. (2002). Reverend Billy: Preaching, protest, and postindustrial flânerie. The Drama Review, 46(1), 60-84.

Lasn, K. (1999). Culture jam: How to reverse America's suicidal consumer binge—and why we must. New York: HarperCollins.

Lasn, K. (2006). We were a bunch of burnt-out activists. Adbusters \#65, 14(3), 85.

Martin, G. (2005). You can't be neutral on a moving bus: Critical pedagogy as community praxis. Journal for Critical Education Policy Studies, 3(2). Retrieved January 7, 2007, from http://www.jceps.com/?pageID=article\&articleID $=47$

Mayo, P. (2002). Public pedagogy and the quest for a substantive democracy. Interchange, 33(2), 193-207.

McKee, A. (2003). Textual analysis. London: Sage.

McLaren, P. (2005). Critical pedagogy in the age of neoliberal globalization. In P. McLaren (Ed.), Capitalists and conquerors: A critical pedagogy against empire (pp. 19-74). Lanham, MD: Rowman \& Littlefield.

Media Education Foundation. (2003). Captive audience. Northampton, MA: Media Education Foundation.

Miriam. (2004). To market, to market. Retrieved January 7, 2007, from http:// www.flinknet.com/theflink/archives/000092.html

Pinar, W. F. (2004). What is curriculum theory? Mahwah, NJ: Lawrence Erlbaum.

Post, D., \& Palacios, L. (2006). Reverend Billy and the Church of Stop Shopping. go kart films and play loud! productions.

Pozo, M. A. (2005). Henry Giroux and the politics of higher education under George W. Bush: An interview. The Review of Education, Pedagogy, and Cultural Studies, 27, 95-107.

Reverend Billy and the Church of Stop Shopping. (n.d.). Campaigns: Retail interventions. Retrieved January 5, 2007, from http:/ / www.revbilly.com/campaigns/ interventions.php

Reynolds, W. M. (2004). To touch the clouds standing on top of a Maytag refrigerator: Brand-name postmodernity and a Deleuzian "in-between." In W. M. Reynolds \& J. A. Webber (Eds.), Expanding curriculum theory: Dis/positions and lines of flight (pp. 19-33). Mahwah, NJ: Lawrence Erlbaum.

Rojek, C. (2001). Leisure and life politics. Leisure Studies, 23, 115-125.

Rumbo, J. D. (2002). Consumer resistance in a world of advertising clutter: The case of Adbusters. Psychology \& Marketing, 19(2), 127-148.

Sandlin, J. A. (2005). Culture, consumption, and adult education: Re-fashioning consumer education for adults as a political site using a cultural studies framework. Adult Education Quarterly, 55(3), 1-17. 
Sandlin, J. A., \& Callahan, J. L. (2004). Creating consumer resistance through Adbusters: Managing emotion beyond organizational boundaries. In T. M. Egan \& L. Morris (Eds.), Proceedings of the 2004 Academy of Human Resource Development Conference (pp. 234-241). Bowling Green, OH: Academy of Human Resource Development.

Sandlin, J. A., \& Milam, J. L. (2007). Culture jamming as curriculum: Exploring the critical public pedagogy of Adbusters and Reverend Billy. In S. Leafgren, B. Schultz, M. O’Malley, L. Johnson, J. Brady, \& A. Dentith (Eds.), The articulation of curriculum and pedagogy for a just society: Advocacy, artistry, and activism (pp. 131-150). Troy, NY: Educator's International Press.

Sandlin, J. A., Milam, J. L., O’Malley, M. P., \& Burdick, J. (2007, October 4). (Re)considering public pedagogy: A critical literature review. Paper presented at the Curriculum \& Pedagogy Conference, Marble Falls, TX.

Sharpe, J. (2001). Culture jam: Hijacking commercial culture. Vancouver, BC: Right to Jam Productions.

Shopper Trak RCT Corporation. (2007). Holiday shopping season starts with a bang. Press Releases. Retrieved November 27, 2007, from http:// www.shoppertrak.com/news_retail_sales_112407.php

Solórzano, D. G., \& Delgado Bernal, D. (2001). Examining transformational resistance through a critical race and LatCrit theory framework. Urban Education, $36(3), 308-342$.

Spring, J. (2003). Educating the consumer-citizen. Mahwah, NJ: Lawrence Erlbaum.

Springgay, S. (2005). Thinking through bodies: Bodied encounters and the process of meaning making in an e-mail generated art project. Studies in Art Education, 47(1), 34-50.

Springgay, S., \& Freedman, D. (2007). Introduction: On touching and a bodied curriculum. In S. Springgay \& D. Freedman (Eds.), Curriculum and the cultural body (pp. xvii-xxvii). New York: Peter Lang.

St. Clair, R. (1998). On the commonplace: Reclaiming community in adult education. Adult Education Quarterly, 49(1), 5-14.

Storey, J. (1999). Cultural consumption and everyday life. London: Arnold.

Storey, J. (2006). Cultural theory and popular culture (4th ed.). Athens: University of Georgia Press.

Stuhr, P. (2003). A tale of why social and cultural content is often excluded from art education-and why it should not be. Studies in Art Education, 44(4), 301-314.

Sulli. (2002). 86. Re: Buy something day. Retrieved January 7, 2007, from http:// www.plastic.com/article.html;sid=02/11/26/18215572

Talen, B. (2003). What should I do if Reverend Billy is in my store? New York: The New Press.

Tavin, K. (2003). Engaging advertisement: Looking for meaning in and through art education. Visual Arts Research, 28(2), 38-47.

Tavin, K., \& Anderson, D. (2003). Teaching (popular) visual culture: Deconstructing Disney in the elementary art classroom. Art Education, 56(3), 21-23 and 32-35.

Tavin, K., Lovelace, L., Stabler, A., \& Maxam, J. (2003). From Bucktown to Niketown: Doing visual cultural studies (Chicago style). Journal of Social Theory on Art Education, 23, 60-88.

Tietchen, T. (2001). Language out of language: Excavating the roots of culture jamming and postmodern activism from William S. Burroughs' Nova trilogy. Discourse, 23(3), 107-129.

Unattributed artist. (2003). Is your life a project? Adbusters \#49, 11(5), 88-89.

Usher, R., Bryant, I., \& Johnston, R. (1997). Adult education and the postmodern challenge. London: Routledge.

Weiss, G. (1999). Body image: Embodiment as intercorporeality. New York: Routledge. 